\title{
INCLUSION CRITERIA FOR ADULTS' VOLUNTARY HOSPITALIZATION IN PSYCHIATRY
}

Filipa Martins Alves, Daniela Brandão, Teresa Novo

Department of Psychiatry and Mental Health, Local Health Unit of Alto Minho, EPE, Viana do Castelo, Portugal.

OBJECTIVES: Reflect on criteria underlying the medical decision of psychiatric hospitalization and define criteria for Voluntary Internment.

BACKGROUND AND AIMS: Psychiatric patients in Portugal are primarily treated on an outpatient basis. However, especially in the Emergency Department, very psychopathologically unbalanced patients show up, requiring immediate hospitalization, in order to be stabilized in the shortest time and to proceed with outpatient treatment. The current Mental Health Law provides for voluntary and compulsive hospitalization. There is a clear enough law to regulate compulsive hospitalization. This is not the case with regard to voluntary hospitalization, for which we did not find the presentation of criteria at the national level.

MATERIALS AND METHODS: Decree laws and guidelines emanating from the General Directorate of Health focused on the Mental Health Act. Reading, information gathering and critical reflection.

\section{RESULTS}

The treatment of some mental disorders, due to its severity, requires the hospitalization in general hospitals, since it is verified that the ambulatory attendance does not allow to reach the state of health and well being desirable. In this context, at the top of the needs of Complete Internment, volunteer or not, are naturally (Table 1):

\section{TABLE 1. CRITERIA FOR VOLUNTARY HOSPITALIZATION IN PSYCHIATRY}

Active suicidal ideations with or without previously experienced attempts.

Straight and self-injurious / injurious behavior of physical and / or psychic integrity.

Primary or secondary psychoses to the use and abuse of alcohol and / or psychoactive substances.

Patients with mental pathology referenced by FGM or accompanied by an outpatient Psychiatrist, either in an outpatient clinic in the NHS or in a private clinic, during a psychopathological decompensation / aggravation phase. These should be reassessed and interned if this is the best way to return them to health and well-being.

Serious disabling anxiety disorders and mood disorders, rendering the person dysfunctional, having to be hospitalized for the shortest possible time, passing as soon as possible to the outpatient regimen.

All the diagnoses contained in the Manuals ICD-11 and DSM-5 and, therefore, recognized as psychopathologies, that before the evaluation by psychiatrists present seriousness that justifies the need and benefit from hospitalization.

\section{CONCLUSIONS}

In the absence of explicit criteria, based on clinical practice, we have established some criteria based on the Good Sence and Superior Interest of the patient for whom the internment presents itself as the only model of treatment capable of returning health and well-being to the mentally ill patient.

The hospitalization should occur tendentially in the general hospitals closest to the home and the treatment should be changed to an outpatient clinic (consultation or Day Hospital) as soon as possible.

\section{REFERENCES}

Decreto-Lei no 36/98 de 24 de julho. In: Diário da República.; Decreto-Lei no 35/99. In: Diário da República.; Decreto-Lei no 304/2009. In: Diário da República.; Xavier, M e Carvalho, A. Internamento Compulsivo em Portugal - contexto e procedimentos. DGS; Uniica. Como, quando e por que internar o paciente psiquiátrico. 12 de maio de 2016. In: http://uniica.com.br/artigo/como-quando-e-por-que-internar-o-paciente-psiquiatrico/; Loureiro CSA. Primeiro contacto com o internamento em Psiquiatria: reações e expectativas da família. Dissertação. Porto 2014. 